CEMA Instituto Universitario

Av. Cordoba 374

1054 Capital Federal

TE. 314-2269

FAX 314-1654

POLITICAL STABILIZATION CVCLES IN HIGH INELATION ECONOMIES

Ernesto H. Stein

$$
\begin{gathered}
\text { Y } \\
\text { Jorge M. Streb } \\
\text { Octubre } 1997 \\
\mathrm{~N}^{\circ} 123
\end{gathered}
$$




\title{
Political Stabilization Cycles in High Inflation Economies*
}

\author{
Ernesto H. Stein \\ and \\ Jorge M. Streb
}

October 1997

JEL classification codes: E31, D72.

Key words: Inflation cycles, elections, political economy.

Abstract: High inflation economies often exhibit stop-go cycles of inflation, rather than smooth inflationary processes. This paper relates these stop-go episodes of inflation to a political cycle: the government can try to repress inflation until after the elections in order to increase the chances of being reelected. This is modeled as a two-period game of incomplete information where voters try to pick the most competent government, and inflation (which signals lack of competency) can be lowered by the government in the short run through foreign debt accumulation. Several stabilization episodes, such as the Primavera Plan in Argentina and the Cruzado Plan in Brazil, are used to motivate the model.

\footnotetext{
"Ernesto H. Stein, Inter-American Development Bank; 1300 New York Ave. N.W., Washington, D.C. 20577; tel. 202-623-2823; fax 202-623-2481; e-mail ernestos@iadb.org. Jorge M. Streb, Centro de Estudios Macroeconómicos de Argentina; Av. Córdoba 374, 1054 Buenos Aires, Argentina; tel. 54-1-314-1757; fax 54-1-314-1654; e-mail streb@cema.edu.ar.
} 


\section{Political stabilization cycles in high inflation economies**}

\section{Introduction}

Stop-go cycles of inflation and recurrent balance of payment crises have been widely observed in high inflation economies. The failure to explain this stop-go pattern with purely economic factors has led some authors to explore political economy explanations for this phenomenon. Mondino, Sturzenegger and Tomassi (1994) and Zarazaga (1994), for example, explain these cycles as a result of a succession of periods of competition among interest groups for government subsidies, during which inflation increases, and periods of "cooperation", during which deficits decline and inflation recedes. These authors, however, do not give any role in this process to an opportunistic government, and offer no predictions regarding the timing of the inflation cycles. We approach these cycles as a manifestation of the political business cycle. Thus, an opportunistic government provides, in our paper, a link between the timing of price stabilizations and elections.

The traditional view on political business cycles, first suggested by Nordhaus (1975), relies on the assumption of voter myopia, and on a short run trade-off between inflation and unemployment. In order to enhance its reelection chances, the government reduces unemployment before elections, at the cost of increased inflation, which is only observed after a lag, once elections have taken place. Modern versions of political cycles depart from the myopia assumption, treating expectations as rational but allowing for incomplete information. Rogoff (1990), for example, models political budget cycles as the equilibrium outcome of a signaling game between voters and the government. It is this modeling approach that will be

**The authors are grateful to George Akerlof, Chris Canavan, Alessandra Casella, Eduardo FernándezArias, Albert Fishlow, Maurice Obstfeld, Robert Powell, Mathew Rabin, David Romer, Andrew Rose, an anonymous referee and members of our dissertation group at UC Berkeley for helpful comments and discussions. We also thank seminar participants at the Universidad de San Andrés, the Instituto Di Tella and the 1994 Latin American Meeting of the Econometric Society. Deborah Davis provided editorial assistance. An earlier version of this paper was published as a CIDER Working Paper in August 1994. The views expressed here are the authors and do not necessarily represent those of their institutions. 
followed in this paper.

Sometimes the critical issue before elections is inflation, rather than employment, providing incentives for politicians to bring prices under control. Moreover, stabilizations are not always contractionary. Under exchange rate-based stabilizations, output often increases in the short run, led by consumption booms (Calvo and Végh, 1992). Incentives to stabilize prices then become stronger. These stabilizations, however, can give rise to a different trade-off, namely one between present and future inflation. Opportunistic politicians can exploit this trade-off in an effort to win elections.

In Section Two we briefly review several stabilization episodes based on pegging exchange rates. We believe political considerations played an important role in determining the timing of these episodes. The crucial point is that, even in the absence of serious fiscal adjustment, a government can stabilize prices in the short run if it has reserves or it can incur debt. However, these stabilizations can be short lived and end up giving way to inflationary outbursts.

In Section Three, we develop a stylized background model for high inflation economies to capture the trade-off between current and future inflation. By borrowing abroad now, the government shifts the inflation tax burden to the future, when all debt has to be repaid. Thus, attempts to stabilize prices can build up repressed inflation, inducing the stop-go pattern described in Section Two.

In Section Four, we show how governments can exploit the trade-off between current and future inflation for electoral purposes. The political stabilization cycle is depicted as a two-period signaling game between the government and the voters, as in Persson and Tabellini (1990).Voters are forward-looking rational agents; information asymmetries are introduced by assuming that voters observe inflation immediately, but can only observe foreign debt after a lag. In this setting, the incumbent has an incentive to lean more heavily on debt financing, since low current inflation acts as a signal of competency that increases the incumbent's reelection chances.

Section Five presents our conclusions on the relevance of the present model, suggesting why 
governments tend to postpone devaluations even at the risk of balance of payments crises.

\section{Politically determined price stabilizations in high-inflation countries}

When inflation is high it often displaces unemployment as the key electoral issue. Inflation stabilization is not necessarily associated with higher unemployment. While orthodox money-based programs are contractionary in the short run, exchange rate-based stabilizations often lead to a boom in the short-run, only to give way to a recession later (Kiguel and Liviatan, 1992). The lack of an immediate cost in terms of increased unemployment may provide strong incentives for the government to control inflation before elections, using the exchange rate as a nominal anchor. ${ }^{1}$

We argue that political motivation has had an important role in the timing of several stabilization episodes. In particular, the Austral, Primavera and Convertibility Plans in Argentina, the Cruzado and Real Plans in Brazil, and the Pacto in Mexico, all started a few months before elections. In each one of these cases, a reduction of the rate of crawl or an exchange rate freeze was an important component of the program (sometimes accompanied by price freezes).

Moreover, there is evidence of a close relationship between the initial success of these programs and the outcome of elections. For example, the last stage of the Real Plan in Brazil, launched on July 1, 1994, shortly ahead of the October presidential elections, was specifically timed to help the official candidate, Cardoso, who was badly trailing in the opinion polls. ${ }^{2}$ The Real was highly successful both in bringing down inflation and in boosting the popularity of the official candidate, who ended up winning the elections. Table 1 shows the evolution of voting intentions prior to the elections, and the final electoral result.

[Table 1: Real Plan and voting intentions]

In some episodes, such as Mexico's Pacto of December 1987, which occurred nine months before

${ }^{1}$ For simplicity, in our model in Sections Three and Four, we will abstract from these output effects, assuming that output is independent of inflation and exogenously fixed.

${ }^{2}$ Cf. Gilberto Dimenstein and Josias de Souza, A Historia Real, quoted in Página 12, October 5, 1994. 
the elections, or the February 1991 Convertibility Plan in Argentina, seven months prior to congressional elections, the stabilization effort was accompanied by substantial fiscal adjustment, and the rate of inflation remained low after the elections.

But in other episodes, such as Brazil's February 1986 Cruzado Plan, nine months before congressional elections, inflation increased immediately after the elections. In reference to this stabilization program, Eliana Cardoso (1991) writes:

"Inflation was zero. For a few months it seemed true, and general euphoria set in. But signs of disequilibrium from excess demand mounted without eliciting an adequate compensatory response. Another election loomed, and, in the best Brazilian political tradition, corrective actions were placed on hold. This time the new measures were announced immediately after the elections .... The deterioration in the balance of payments became as significant as the mounting internal problem. Suddenly, Brazil's comfortable cushion of reserves, which could lend credibility to the maintenance of a fixed exchange rate, had vanished." (pp. 152-3).

The government deliberately postponed a large devaluation until after the elections in order to keep inflation under control (Figure 1). This postponement had severe consequences for Brazil's current account, which reached a deficit of nearly four billion dollars in the fourth quarter of 1986.

The Primavera Plan in Argentina, launched nine months before the May 1989 presidential elections, is an unsuccessful example of this strategy. Heymann (1991) states that "The announcement of the Primavera program in August 1988 was widely perceived as a final attempt to moderate inflation before the 1989 presidential elections" (p. 105). One of the main elements was the reduction of the rate of crawl, but speculative attacks on the exchange rate and the suspension of external loans prevented the government from postponing the devaluation until after the elections, causing prices to bounce back up with disastrous electoral consequences for the Radical Party, in office at the time (Figure 2). The reduction of the rate of crawl resulted again in current account deficits, associated with the lack of credibility of the policy: exporters had incentives to delay their shipments in expectation of a large devaluation, which in fact occurred.

Israel in 1988 and Bolivia in 1989 are further examples of postponements of devaluations to slow down inflation before elections, according to Bruno and Meridor (1991) and Morales (1991). The Mexican 
peso crisis at the end of 1994 can be interpreted in the same way: the Salinas administration delayed the devaluation, even when reserves were declining at a very rapid pace. In this case, the devaluation only happened once the new government was in office.

The evidence indicates that, absent a serious effort on the fiscal side, exchange rate-based stabilizations keep inflation under check for a limited time only. Eventually, exchange rate adjustments become necessary to avert a balance of payments crisis, or occur as a result of such crises. At the same time, these episodes show that governments indeed have the possibility of "repressing" inflation, shifting it from the present to the future. Rather than the traditional inflation-unemployment trade-off, the key element seems to be an intertemporal trade-off between inflation today and inflation tomorrow, which governments have exploited for political purposes. In Sections Three and Four we build a model consistent with this pattern.

In addition to the stop-go cycles of inflation, these price stabilizations result in an appreciation of the real exchange rate and, until devaluations occur, in current account deficits. ${ }^{3}$ Since we work with a onesector model, there is no distinction between prices and exchange rates, so we cannot capture the real appreciation of the exchange rate. We do capture, however, the current account deficits associated with these real appreciations prior to elections.

\section{The background model}

We develop here a two-period model in the spirit of Sargent and Wallace (1981): if the government doesn't undertake a fiscal adjustment, substituting debt financing for the inflation tax today only leads to a transitory reduction of inflation and even more inflation tomorrow. It is a stylized version for high inflation economies, where output is fixed and prices are driven by changes in money, fitting the Lucas (1973)

\footnotetext{
${ }^{3}$ Successful exchange rate-based stabilizations programs, where inflation has been kept under control for extended periods of time, have also resulted in substantial real appreciation and important current account deficits. In Calvo and Végh (1990) a successful stabilization brings about a permanent real appreciation; in De Gregorio, Guidotti, and Végh (1992) it initially causes a current account deficit.
} 
characterization of high inflation economies as more Classical.

\section{a. Real endowments and international trade}

An exogenous amount of a single perishable good, $y_{\mathfrak{t}}$, is available each period for private consumption, or for its transformation by the government into a public good. Private consumption $c_{t}$ plus public consumption $\mathrm{g}_{\mathrm{t}}$ equals output $\mathrm{y}_{\mathrm{t}}$ minus net exports $\mathrm{nx}_{\mathrm{t}}$, all in per capita terms.

International trade is a device to engage in intertemporal trade: the government can trade with foreigners in the spot and futures market. An exogenous interest rate $i$ applies to the external debt $d_{t}$. The change in the external debt is explained by the trade deficit and the interest accrued on previous debt: $d_{t}-d_{t-1}$ $=-n x_{t}+i d_{t-1}$. The end value of external debt is constrained to be zero, and so is the initial debt: $d_{0}=d_{2}=0$. The only crucial point, however, is that a final debt ceiling exist in period two. Since the government is the only one with access to the international capital market, the foreign debt it incurs in the first period is identical to the trade deficit.

\section{b. Budget restrictions, money and prices}

The intertemporal restriction for the economy implies that, in terms of present value, private consumption equals production net of government expenditure:

$$
c_{1}+\frac{C_{2}}{1+i}=A, \text { where } A \equiv y_{1}+\frac{y_{2}}{1+i}-\left(g_{1}+\frac{g_{2}}{1+i}\right)
$$

Households receive an initial monetary endowment, which we normalize to equal the present discounted value of output times an arbitrary initial price level, $\mathrm{M}_{0}=\left(\mathrm{y}_{1}+\mathrm{y}_{2} /(1+\mathrm{i})\right) \mathrm{p}_{0}$. This monetary advance is used to consume over two periods. The desire to consume in period two can induce a positive demand for money $\mathrm{M}_{1}{ }^{\mathrm{d}}$ in period one. Money is the only asset they can hold. The per-period budget constraint depends on the prices in effect each period, or equivalently on inflation in periods one and two, where inflation $\pi_{t}$ is $\left(\mathrm{p}_{t}-\mathrm{p}_{\mathrm{t}-1}\right) / \mathrm{p}_{\mathrm{t}-1}$. 


$$
C_{1}+\frac{M_{1}^{d}}{p_{1}} \equiv \frac{M_{0} / p_{0}}{1+\Pi_{1}}, \quad C_{2} \equiv \frac{M_{1}^{d} / p_{1}}{1+\Pi_{2}}
$$

The government can either issue money or incur foreign debt to finance its expenditures. Denoting the nominal exchange rate $e_{t}$, the budget restriction the government faces each period is that the money it prints plus the domestic value of the proceeds from external borrowing equal expenditures on the public good plus the domestic value of the interest on foreign debt (if $\mathrm{d}_{t-1}$ is negative, the government receives an interest payment): $\Delta M_{t}+e_{t} \Delta d_{t}=p_{t} g_{t}+e_{t} i d_{t-1}$.

We assume that the international price $\mathrm{p}^{*}$ of the good is fixed at one. By purchasing power parity, $e_{t}=p_{1}$. Change in the money supply follows from the per-period budget constraints: it is less than expenditures when the government becomes indebted, and more when debt is repaid.

$$
\Delta M_{1}=p_{1}\left(g_{1}-d_{1}\right), \quad \Delta M_{2}=p_{2}\left(g_{2}+(1+i) d_{1}\right)
$$

The nominal price $\mathrm{p}_{\mathrm{t}}$ is determined so as to clear the market each period, and is directly proportional to the amount of money spent by consumers and the government during each period.

$$
p_{1}=\frac{\left(M_{0}-M_{1}^{d}\right)+\Delta M_{1}}{Y_{1}}, \quad p_{2}=\frac{M_{1}^{d}+\Delta M_{2}}{y_{2}}
$$

\section{c. Household and voter preferences}

Utility of a representative agent in period $t$ is a concave function of consumption, with constant relative risk aversion (CRRA) between 0 and $1 .{ }^{4}$ We assume that a constant amount of public good is provided by the government each period, so it is not included explicitly in the utility function (only its cost of production varies, as will be seen in Section Four). Total utility is additive in the per-period functions of consumption, and the future is discounted at a rate delta, $0<\delta \leq 1$ :

${ }^{4}$ We consider $u\left(c_{t}\right)=c_{t}^{1 / m}$, for any $m>1$. The coefficient of relative risk aversion is $\varepsilon=-\left[u\left(c_{t}\right)^{\prime \prime} / u\left(c_{t}\right)^{\prime}\right] c_{t}=(1-$ $1 / \mathrm{m})$. Log-utility is also a member of this class, with $\varepsilon=1$. 


$$
U\left(c_{1}, c_{2}\right)=u\left(c_{1}\right)+\delta u\left(c_{2}\right)
$$

The first-order condition that relates consumption in both periods, from (2) and (5), is:

$$
u^{\prime}\left(c_{1}\right)=\frac{\delta}{1+\Pi_{2}} u^{\prime}\left(c_{2}\right)
$$

\section{d. Consumption decisions, money demand and the inflation tax}

First period consumption and money demand (or, equivalently, first and second period consumption) can be obtained from the household budget constraint (2) and first order condition (6), as functions of inflation rates in both periods.

$$
\begin{aligned}
& C_{1}^{*}=\frac{\left(1+\Pi_{2}\right)^{(1-\varepsilon) / \varepsilon}}{\left(1+\Pi_{2}\right)^{(1-\varepsilon) / \varepsilon}+\delta^{1 / \varepsilon}} \frac{M_{0} / P_{0}}{1+\Pi_{1}} \\
& \frac{M_{1}^{a^{*}}}{P_{1}}=\frac{\delta^{1 / \varepsilon}}{\left(1+\Pi_{2}\right)^{(1-\varepsilon) / \varepsilon}+\delta^{1 / \varepsilon}} \frac{M_{0} / P_{0}}{1+\Pi_{1}}
\end{aligned}
$$

Notice that for the class of CRRA utility functions we analyze, with $0<\varepsilon \leq 1$, money demand falls with an increase in the expected rate of inflation in the second period, except for $\log$ utility, where $e=1$, and money demand does not depend on second period inflation. Consumers dislike inflation because it taxes money balances. Inflation tax revenues increase with $\pi_{1}$, since there is only an income effect. An increase in $\pi_{2}$, in contrast, has both income and substitution effects. A Laffer effect may arise if the tax rate on money balances, $\pi_{2} /\left(1+\pi_{2}\right)$, exceeds a certain limit.

\section{e. Trade-off between current and future inflation}

The link between present and future consumption in the overall transformation frontier leads to a link between present and future inflation. This relationship is initially negative, starting at the optimal inflation for a social planner, given by $1+\pi_{2}=1 /(1+i)$. Inflation in the second period falls as first period inflation 
increases, and this trade-off continues as long as the expression in brackets below, which decreases monotonically in $\pi_{2}$, continues to be non-negative: ${ }^{5}$

$$
\begin{gathered}
\frac{d \Pi_{1}}{d \Pi_{2}}=-\frac{\frac{\partial c_{1}}{\partial \Pi_{2}}+\frac{1}{1+i} \frac{\partial c_{2}}{\partial \Pi_{2}}}{\frac{\partial c_{1}}{\partial \Pi_{1}}+\frac{1}{1+i} \frac{\partial c_{2}}{\partial \Pi_{1}}} \\
=-\frac{\left(M_{0} / P_{0}\right)}{(1+i) A} \frac{\delta^{1 / \varepsilon}}{\left[\left(1+\Pi_{2}\right)^{1 / \varepsilon}+\delta^{1 / \varepsilon}\left(1+\Pi_{2}\right)\right]^{2}}\left[\frac{1}{\varepsilon}+\frac{\delta^{1 / \varepsilon}}{\left(1+\Pi_{2}\right)^{(1-\varepsilon) / \varepsilon}}-(1+i) \frac{1-\varepsilon}{\varepsilon}\left(1+\Pi_{2}\right)\right]
\end{gathered}
$$

Figure 3 shows the relationship between first and second period inflation. The intuition for the shape of the curve is as follows: for high values of expected inflation, the Laffer effect makes tax revenues fall with increases in $\pi_{2}$. When this happens, $\pi_{1}$ has to increase to meet the government's budget constraint. This implies that for some values of $\pi_{1}$, second period inflation is not defined uniquely. For these values, consumption decisions depend on which of the two $\pi_{2}$ is expected (with log utility, there is an inverse relation for all values of $\pi_{2}$ ).

To solve the coordination problem for consumers, we restrict the feasible range of expected $\pi_{2}$ by imposing the condition that all consumers expect the lower of these two inflation rates. In other words, we impose an upper bound on $\pi_{2}{ }^{\mathrm{e}}$, defined as the point where $\mathrm{d} \pi_{1} / \mathrm{d} \pi_{2}=0$. The lowest first-period inflation rate the government can send as a signal is precisely the one that corresponds to the upper bound for $\pi_{2}^{\circ}$. A motivation for restricting expectations in this way is that the low inflation equilibrium is the one that leaves everyone better off. Given this restriction on beliefs, there is a negative relationship between first and second period inflation. Furthermore, there is a unique correspondence between values of $c_{1}$ and $\pi_{1}$ : consumption increases as inflation falls.

${ }^{5}$ The condition for the brackets to be non-negative, with $\varepsilon<1$, is more stringent than the condition that rules out the Laffer effect: to rule out the latter requires that the brackets be non-negative, but the factor $(1+i)$ does not figure in the third term in brackets. 
The inflation trade-off is the key intertemporal link in the model, capturing the fact that inflation can be repressed in the short run but not in the long run. Debt shifts the inflation tax burden between the first and the second period. While a social planner would not try to exploit this trade-off, an office-motivated politician will. We explore the consequences of this in Section Four.

\section{The game}

We follow the procedure in Persson and Tabellini (1990, ch. 5) on elections and government signaling. ${ }^{6}$ Candidates differ in their competence, which is reflected in the size of the budget deficit. They care for the welfare of society, but they also enjoy the perks of holding office. The main difference with Persson and Tabellini is that here the signal is inflation rather than output.

After presenting the benchmark case of complete information, we study the consequences of incomplete information, where voters can observe inflation but debt is not observable. This assumption is motivated by the historical record of deficient information on fiscal accounts and net public debt in Latin American countries. Though the competent would have incentives to provide information in order to reveal its type, unless this information is easily verifiable the incompetent could mimic the competent, rendering the information useless. ${ }^{7}$

The timing of the game is as follows: the incumbent government moves first, choosing the money/debt mix to finance its deficit. Then everybody observes inflation $\pi_{1}$ but not debt $\mathrm{d}_{1}$. Finally, elections are held. Given this setup, an office-motivated incumbent can have an incentive to incur debt and distort inflation downward in the first period in order to be reelected. To simplify the exposition, we will show that lower inflation is associated with a higher level of consumption. This allows a high $\mathrm{c}_{1}$ to be the signal of

${ }^{6}$ They draw in turn on Cukierman and Meltzer (1986), Rogoff and Sibert (1988), and Rogoff (1990).

${ }^{7}$ The informational constraints could be relaxed if the government had the option of allowing an external auditor to monitor government accounts. Actions of this type include supervision by the IMF, or scrutiny by Congress. This option to address the problem of lack of transparency of government accounts is not analyzed in this paper, but it should be an important consideration in the design of institutional reforms. 
government competency.

\section{a. Elections under complete information}

There are two government types, competent (c) and incompetent (nc). They differ in their efficiency in producing the required level of public good. The per capita expenditure and the budget deficit are lower with a competent government: $\mathrm{g}^{\mathrm{c}}<\mathrm{g}^{\mathrm{nc}}$. Let $\mathrm{i}$ denote the incumbent in the first period and $\mathrm{j}$ the incumbent in the second period. Total consumption is lower with incompetent governments, since resources available for consumption $\left(A^{i j}\right)$ are lower when either $i$ or $j=n c$.

The incumbent government derives utility from the welfare of voters. Unlike a pure social planner, it also derives utility from the perks of being in office $\left(s_{t}=1\right)$.

$$
\begin{aligned}
& V\left(c_{1}, c_{2}, s_{1}, s_{2}\right)=u\left(c_{1}\right)+v\left(s_{1}\right)+\delta\left[u\left(c_{2}\right)+v\left(s_{2}\right)\right], \\
& \text { where } s_{t} \in\{0,1\}, v(0)=0, v(1)>0
\end{aligned}
$$

Elections provide a way of sorting out incompetent governments. If the incumbent is not reelected, a new candidate is chosen at random from the population of voters, who can be either competent, with probability q, or incompetent, with probability 1-q. The solution concept under complete information is subgame perfect equilibrium, proceeding by backwards induction. Utility for voters is higher when the government in the second period is competent (Lemma 1 in Appendix). Thus, a competent incumbent will be reelected, so $\operatorname{Pr}($ reel $c)=1$, while an incompetent one will not, $\operatorname{Pr}($ reel nc $)=0$.

Given voters' reactions, in the first period there are two decision problems, one for each government type. Expected utility is conditional on the incumbent's type.

$$
\begin{aligned}
& \operatorname{Max} E V\left(c_{1} / i\right)=u\left(c_{1}\right)+v(1)+\delta \operatorname{Pr}(\operatorname{reel} i)\left[u\left(c_{2}^{i, i}\left(c_{1}\right)\right)+v(1)\right] \\
& C_{1} \\
& +\delta(1-\operatorname{Pr}(\operatorname{ree} 1 i))\left[q u\left(c_{2}^{i, c}\left(c_{1}\right)\right)+(1-q) u\left(c_{2}^{i, n c}\left(c_{1}\right)\right)\right], \\
& \text { where } c_{2}^{i, j}\left(c_{1}\right) \text { is given by } c_{1}+\frac{c_{2}^{i, j}}{1+i}=A^{i, j} \text {, for } i, j \in\{c, n c\} \text {. }
\end{aligned}
$$

The first order conditions are analogous to the solution reached by a social planner: 


$$
\begin{aligned}
& i=c \Rightarrow u\left(c_{1}^{c}\right)=\delta(1+i) u\left(c_{2}^{c, c}\right) \\
& i=n c \Rightarrow u^{\prime}\left(c_{1}^{n c}\right)=\delta(1+i)\left[q u^{\prime}\left(c_{2}^{n c, c}\right)+(1-q) u^{\prime}\left(c_{2}^{n c, n c}\right)\right]
\end{aligned}
$$

Since resources $\mathrm{A}^{\mathrm{i}, \mathrm{j}}$ available for consumption are larger under competent governments, it is easy to infer from the first order conditions that $\mathrm{c}_{1}{ }^{>}>\mathrm{c}_{1}{ }^{\text {nc; }}$; i.e., consumption in the first period will be higher with a competent government. ${ }^{8}$ What about first period inflation? With log utility, the reasoning is straightforward: since $c_{1}$ only depends on $\pi_{1}$, inflation has to be lower with a competent government. The same result holds in general: $\pi_{1}{ }^{\mathrm{c}}<\pi_{1}{ }^{\mathrm{nc}}$ (Lemma 2). From this point on we work with $\mathrm{c}_{1}$, instead of $\pi_{1}$, as shorthand for the signal the government sends in the first period. It is a matter of algebra to find the inflation rates necessary to implement a given level of consumption.

\section{b. Elections under incomplete information}

Under complete information, the political incentive to be reelected does not introduce any distortions, but under incomplete information it does. The nature of the equilibrium depends on the beliefs of voters. The solution concept is perfect Bayesian equilibrium, introducing the intuitive criterion (Cho and Kreps, 1987) to restrict out-of-equilibrium beliefs.

\section{i. Separating equilibrium}

Let the signal that identifies a competent government be $c_{1}{ }^{s}$. Since $c_{1}$ will be either high or low in equilibrium (namely, $\mathrm{c}_{1}{ }^{\mathrm{s}}$ or $\mathrm{c}_{1}{ }^{\mathrm{nc}}$, as established below), beliefs are determined by the equilibrium strategies and Bayes rule for those values of $c_{1}$. The beliefs for out-of-equilibrium values of $c_{1}$, however, are not similarly restricted. If voters expect higher consumption under a competent government, beliefs are updated according to the following scheme:

$$
\begin{aligned}
& c_{1}<c_{1}^{s} \Rightarrow \operatorname{Pr}(\text { reel } i)=0 \\
& c_{1} \geq c_{1}^{s} \Rightarrow \operatorname{Pr}(\text { reel } i)=1
\end{aligned}
$$

${ }^{8}$ Since $c_{2}{ }^{i, j}=\left(A^{i, j}-c_{1}\right)(1+i)$ and $u\left(c_{2}\right)$ is concave, at $c_{1}=c_{1}^{c}$ that establishes equality in marginal condition for $i=c$, LHS $<$ RHS in marginal condition for $\mathrm{i}=$ nc. Thus, need $\mathrm{c}_{1}{ }^{\mathrm{nc}}<\mathrm{c}_{1}{ }^{\mathrm{c}}$. 
Incompetent government: if equilibrium is separating, the government knows it will not be reelected, picking the same level of consumption $c_{1}{ }^{n c}$ as under complete information, given by first order conditions (11). For $\mathrm{c}_{1}^{\mathrm{s}}$ to be effectively the signal of a competent government in a separating equilibrium, expected utility for an incompetent government has to be lower with $c_{1}{ }^{s}$ than with $c_{1}{ }^{\text {nc }}$ : the temptation $T$ to deviate from $\mathrm{c}_{1}{ }^{\text {nc }}$ to $\mathrm{c}_{1}{ }^{\text {, }}$, which can be expressed as the gain $\mathrm{G}$ minus the cost $\mathrm{C}$ of deviating, must be negative. By convention, the incompetent government doesn't deviate when indifferent:

$$
T\left(c_{1}, c_{1} / n C\right)=G\left(c_{1}, c_{1} / n C\right)-C\left(c_{1}, c_{1} / n C\right) \leq 0
$$

The gain from deviating to $c_{1}{ }^{s}$ is the utility $\delta v(1)$ from being in office during the second period. The cost of deviating is the loss in the expected utility of consumption, which can be broken down into fixed and variable components. The fixed cost is associated with the loss in the expected resources available for consumption in the second period, as the probability of an incompetent being in office jumps from 1-q to 1 , since the incompetent will be reelected with certainty when it plays the signal $\mathrm{c}_{1}{ }^{3}$. As for the variable cost, when the incompetent plays the signal $\mathrm{c}_{1}{ }^{s}$, it departs from the optimal time profile of consumption, choosing a higher consumption than $\mathrm{c}_{1}^{\mathrm{nc}}$, which is the optimal for the case where an incompetent government is in office both periods. The distortion on the time profile of consumption is increasing in $\mathrm{c}_{1}{ }_{1}^{\mathrm{s}}$.

Competent government: its signal in a separating equilibrium must satisfy condition (13). If $\mathrm{c}_{1}{ }^{\mathrm{c}}$ of complete information case satisfies this condition, it will be the first-best for a competent government, achieving the optimal consumption profile. Otherwise, it will need to signal with a higher consumption: let it be the level such that (13) is exactly an equality: ${ }^{9}$

$$
c_{1}^{s}=\max \left\{c_{1}^{c}, \max c_{1} \text { s.t. } T\left(c_{1}, c_{1}^{n c} / n c\right)=0\right\}
$$

A competent government actually wants to send this signal, since its cost of signaling is lower than

${ }^{9}$ Working with the signaling cost function, which is convex, it is easy to verify that $T\left(\mathrm{c}_{1}{ }^{\mathrm{s}}, \mathrm{c}_{1}{ }^{\mathrm{n}} / \mathrm{nc}\right)=0$ has two roots. Only the largest of them qualifies as a signal, since the relevant interval for $c_{1}{ }^{s}$ is for values of $c_{1} \geq c_{1}{ }^{c}$. 
that of an incompetent government (Lemma 3). This is depicted in Figure 4, where the relevant interval for signals is $c_{1} \geq c_{1}{ }^{c}$. At a consumption level $c_{1}{ }^{s}$ such that an incompetent is just indifferent between signaling or not, a competent government will be tempted to signal.

Levels below $\mathrm{c}_{1}{ }^{\mathrm{s}}$ can be ruled out for a competent government, because they provide a temptation for the incompetent to signal as well. Levels above $\mathrm{c}_{1}{ }^{s}$ are weakly dominated: the cost of sending a signal is increasing in $\mathrm{c}_{1}$, while the gain is just the same since they provide no additional information. Thus, Proposition 1: provided inflation rates $\pi_{1}^{\mathrm{nc}}, \pi_{\mathrm{l}}^{\mathrm{s}}$ can be found for respective consumption levels, a separating equilibrium exists where an incompetent government picks $\mathrm{c}_{1}=\mathrm{c}_{1}{ }^{\mathrm{nc}}$, and a competent government picks $\mathrm{c}_{1}=\mathrm{c}_{1}{ }^{\mathrm{s}}$ that satisfies condition (14).

There is a caveat: a separating equilibrium may not exist when there is a corner solution. With log utility, whatever the gain $\mathrm{G}\left(\mathrm{c}_{1}, \mathrm{c}_{1}{ }^{\mathrm{nc}} / \mathrm{nc}\right)$ from being reelected, there is always a separating equilibrium because there is no lower bound on $\pi_{1}$. In other cases, there may be no $\pi_{1}^{s}$ to implement $c_{1}^{s}$. This can occur in particular when the utility derived from holding office is sufficiently high, since $\mathrm{c}_{1}{ }^{\text {s }}$ would be high, and a low enough level of first period inflation to implement this consumption might not exist. We will get back to this discussion in our analysis of the pooling equilibrium.

\section{ii. Pooling equilibrium}

Voters expect both types of government to set consumption at $c_{1}{ }^{p}$, which is the consumption that maximizes a competent government's expected utility under pooling. ${ }^{10}$ Since the signal is not informative about the government's type, voters will be indifferent between all candidates, so we assume that the probability of reelection is one half. For off-equilibrium events, we momentarily accept that more consumption does not increase the probability of reelection.

${ }^{10}$ The level of consumption $\mathrm{c}_{1}{ }^{\mathrm{p}}$ is lower than the optimal value of consumption for a competent government under complete information $\mathrm{c}_{1}{ }^{\mathrm{c}}$, since now there is a probability $(1-\mathrm{q}) / 2$ that an incompetent will be elected for the second period. 


$$
\begin{aligned}
& C_{1} \geq c_{1}^{P} \quad \Rightarrow \quad \operatorname{Pr}(\text { reel } i)=\frac{1}{2} \\
& C_{1}<c_{1}^{P} \quad \Rightarrow \quad \operatorname{Pr}(\text { reel } i)=0
\end{aligned}
$$

Competent government: the probability a competent government is in office in the second period is $1 / 2+q / 2$, i.e., the sum of the probability of reelection and the probability of being replaced by a competent if not reelected. The probability an incompetent will take office is $(1-q) / 2$. The level of consumption under the pooling equilibrium is determined by the following first order condition:

$$
u^{\prime}\left(c_{1}^{p}\right)=\delta(1+i)\left[\frac{1+q}{2} u^{\prime}\left(c_{2}^{c, c}\left(c_{1}^{p}\right)+\frac{1-q}{2} u^{\prime}\left(c_{2}^{c, n c}\left(c_{1}^{p}\right)\right)\right]\right.
$$

Incompetent government: we need to verify that an incompetent administration will actually be willing to send this signal. The expected cost for an incompetent government can again be broken down in two, the loss in consumers' expected utility from increasing $\operatorname{Pr}($ reel $\mathrm{nc})$ from 0 to $1 / 2$, plus the distortion from pushing consumption in the first period upwards to mimic a competent government, which is increasing in $c_{1}^{p}$. The expected cost must be less than the expected gain from increasing the probability of staying in office:

$$
T\left(c_{1}^{p}, c_{1}^{n c} / n C\right)=\delta \frac{V(1)}{2}-C\left(c_{1}^{p}, c_{1}^{n c} / n C\right) \geq 0
$$

A case where this condition is satisfied is represented in Figure 5, with $c_{1}=c_{1}{ }^{p}$ for both types of governments, since the reward $v(1)$ from holding onto power exceeds some minimum level. ${ }^{11}$

Does the pooling equilibrium survive the temptation of a competent government to separate out? Applying the intuitive criterion, which places restrictions on the beliefs about off-equilibrium events, consider a deviation by the competent government from $c_{1}{ }^{p}$ with a signal $c_{1}{ }^{d}$. The potential deviation can be found computing the $c_{1}$ where the incompetent is indifferent between the expected gain, half the utility $\delta v(1)$ from

${ }^{11}$ If the utility $\mathrm{v}(1)$ from being in office is smaller than necessary for a pooling equilibrium, a semi-separating equilibrium is possible. However, with the refinement, the semi-separating equilibrium can be eliminated. 
holding political office, and the cost, the distortion in the optimal time profile of consumption plus the reduction in the resources available for consumption when $\operatorname{Pr}($ reel nc) rises from $1 / 2$ to 1 .

If the competent is tempted to deviate to $c_{1}{ }^{d}$, voters can infer the incumbent is signaling to make them revise their beliefs and raise $\operatorname{Pr}($ reel i) from $1 / 2$ to 1 . Hence, voters will not expect a competent government to ever send the pooling signal in the first place. The condition for the pooling equilibrium to stand is thus

$$
T\left(c_{1}^{d}, C_{1}^{p} / C\right)=\delta \frac{V\left(S_{2}\right)}{2}-C\left(C_{1}^{d}, C_{1}^{p} / C\right) \leq 0
$$

The cost of deviating from pooling equilibrium is lower for a competent government (Lemma 4), so the competent will deviate as long as a $\pi_{1}{ }^{d}$ exists to implement $c_{1}{ }^{d}$. The pooling equilibrium survives only if a corner solution is hit, which is precisely the instance where a separating equilibrium cannot be attained. The likelihood of a pooling equilibrium is larger when reelection (rather than social welfare) is the overriding concern of the incumbent.

Proposition 2: if there is no inflation rate $\pi_{1}^{s}$ to implement $c_{1}^{s}$, then there exists an inflation rate $\pi p_{1}^{p}$ to implement the pooling equilibrium, where $c_{1}=c_{1}{ }^{p}$ for both types of government.

Thus multiple equilibria can be ruled out when out-of-equilibrium beliefs are restricted with forward rationality requirements. There will either be a separating equilibrium, or, when the gain from reelection is the overriding concern of the incumbent, a pooling equilibrium.

\section{iii. Welfare implications}

Is signaling optimal from a social welfare perspective? The answer depends on the type of equilibrium. Under a pooling equilibrium, the incompetent government deviates by mimicking what a competent government would do. This is welfare reducing: it involves a fixed cost, since the probability of an incompetent being elected increases from (1-q) to (1-q/2), and a variable cost, which depends positively on how far the incompetent has to deviate to mimic the competent.

Under separating equilibrium, it is the competent that deviates. In this case, the welfare effects are 
ambiguous. The cost of signaling for the competent has a fixed component that is negative, since the signal ensures that a competent will be in office in the second period. We can call this component a "fixed benefit". This benefit depends, among other things, on the parameter $\mathrm{q}$, being small when $\mathrm{q}$ is close to 1 , since it is likely a competent will reach office anyways. The variable cost component is positive and increasing in $\mathrm{c}_{1}{ }^{\mathrm{s}}$. The signal $c_{1}{ }^{s}$ is greater when the utility of holding office is large and when the difference in competence between the two types is small. Therefore, the variable cost will be larger under those same conditions. Whether signaling by the competent is socially optimal depends on the relative importance of the fixed benefit and the variable cost.

Signaling in the separating equilibrium is more likely to be "good" when the utility of holding office is small, when the difference in competence between both types of government is large, and when q is small. Of all the things that affect the benefit of signaling by the competent, we are most interested in the additional utility (or "perks") derived from holding office. Figure 6 presents the results of a simulation relating these perks and welfare, given that a competent government is in office in period 1 . We worked with the utility

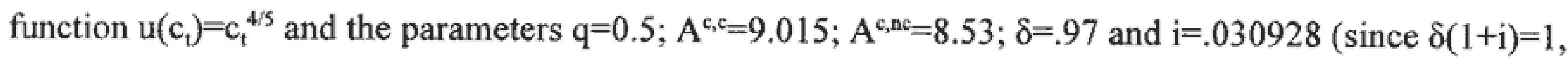
the optimal pattern of consumption is flat).

When perks associated with holding office are small enough, the competent government can play $\mathrm{c}_{1}{ }^{\mathrm{c}}$, which satisfies first order condition (11), achieving the optimal pattern of consumption while at the same time signaling its competence. As the utility of holding office increases, this level will no longer suffice. First period consumption will increase, and welfare decrease as the utility from holding office increases.

If these perks become very large, the incumbent would have to signal with a very high level of first period consumption. The way to implement this is to rely heavily on foreign financing, so that inflation in the first period can be reduced. As we have shown in figure 3, however, there is a lower bound on first period inflation, and thus a higher bound on first period consumption. When $\mathrm{c}_{1}{ }^{s}$ necessary to signal competency is beyond this higher bound, there is a switch to a pooling equilibrium, which results in a downward jump in 
first period consumption (since now there is a chance that an incompetent will be in office in the second period) and an upward jump in expected welfare.

Why does welfare improve with the switch to pooling? Because when the perks are very large, signaling requires a large deviation from the optimal consumption pattern (or a large variable cost) in exchange for the fixed benefit of increasing the chances that a competent will hold office in the second period from $(1+q) / 2$ to 1 . Notice from the graph that for some high values of the utility derived from holding office, society would be better off if the competent does not signal, and loses the election with certainty. This is an example where signaling is not socially optimal.

\section{Conclusions}

We developed a model where low inflation is the signal that the incumbent is competent. This implies a pattern where governments try to reduce inflation before elections, to increase their chances of reelection. This is done by a competent government in a separating equilibrium, when it is not enough for it to signal with the optimal intertemporal rate of inflation, and by an incompetent government in a pooling equilibrium, when it mimics a competent government. Which equilibrium is achieved depends on the importance of the personal gains from reelection: when the stakes of reelection are sufficiently high, there is a pooling equilibrium. Since this is a one sector model, there is no distinction between devaluation and inflation. Another way to interpret the model is that governments tend to defer devaluations until after elections, increasing the trade deficit. The model, therefore, seems to capture some of the most important features of the experiences described in Section Two: the stop-go pattern of inflation and balance of payments crises.

This furnishes a reason for governments to allow exchange rate overvaluation, even at the risk of a balance of payments crisis. ${ }^{12}$ In Krugman (1979), speculative attacks on foreign reserves are modeled as the

\footnotetext{
${ }^{12}$ In this paper, balance of payments crises were not explicitly modeled, since the emphasis was placed on the timing of stabilizations with respect to elections. The model, however, could be extended by allowing currency substitution and introducing uncertainty regarding the availability of foreign financing,
} 
best response by speculators to the government's strategy of pegging the exchange rate. This strategy is treated as exogenous. But why would the government follow such a strategy, when it inevitably will result in a balance of payments crisis? A possible answer, suggested by this paper, is that a fixed exchange rate can act as a nominal anchor for prices. If elections are held before the speculative attack, this strategy can reduce inflation and increase the chances of reelection for the government.

Given the welfare costs of the political manipulation of economic policy by opportunistic governments, a policy implication of this paper is that it is important to foster institutional reform to increase the transparency of government accounts -- including budget deficits, reserves, monetary aggregates, balance of payments accounts and debt -- and make the information readily available to the public. This point was brought home by the Mexican crisis of December 1994.

\section{Appendix}

\section{Lemma 1: Indirect utility is an increasing function of future competency.}

Utility is evaluated at the optimal consumption profile. The first period incumbent is either $\mathrm{i}=\mathrm{nc}$ or $\mathrm{i}=\mathrm{c}$. Let $\rho$ be the likelihood that the second period incumbent is competent:

$$
\begin{aligned}
& \operatorname{Max} E U\left(c_{1} / i\right)=u\left(c_{1}\right)+\delta\left[\rho u\left(c_{2}^{i, c}\left(c_{1}\right)\right)+(1-\rho) u\left(c_{2}^{i, n c}\left(c_{1}\right)\right)\right] \\
& c_{1}
\end{aligned}
$$

For a given $\rho$, the first order condition for $\mathrm{c}_{1}{ }^{\mathrm{i}}$ that maximizes consumers' expected utility can be derived. To see how $c_{1}{ }^{i}$ reacts to changes in $\rho$, the first order condition must be differentiated totally. This yields the result that $c_{1}{ }^{i}$ is an increasing, continuous function of $\rho$ :

$$
\frac{d c_{1}^{i}}{d \rho}=\frac{\delta(1+i)\left[u^{\prime}\left(c_{2}^{i, c}\left(c_{1}{ }^{i}\right)\right)-u^{\prime}\left(c_{2}^{i, n c}\left(c_{1}{ }^{i}\right)\right)\right]}{\left.u^{\prime \prime}\left(c_{1}^{i}\right)+\delta(1+i)^{2}\left[\rho u^{\prime \prime}\left(c_{2}^{i, c}\left(c_{1}{ }^{i}\right)\right)+(1-\rho)\right) u^{\prime \prime}\left(c_{2}^{i, n c}\left(c_{1}{ }^{i}\right)\right)\right]}>0
$$

which affected episodes as the Primavera Plan. For two treatments of rational balance of payments crises, see Guidotti and Végh (1992) and Velasco (1994). 
best response by speculators to the government's strategy of pegging the exchange rate. This strategy is treated as exogenous. But why would the government follow such a strategy, when it inevitably will result in a balance of payments crisis? A possible answer, suggested by this paper, is that a fixed exchange rate can act as a nominal anchor for prices. If elections are held before the speculative attack, this strategy can reduce inflation and increase the chances of reelection for the government.

Given the welfare costs of the political manipulation of economic policy by opportunistic governments, a policy implication of this paper is that it is important to foster institutional reform to increase the transparency of government accounts -- including budget deficits, reserves, monetary aggregates, balance of payments accounts and debt -- and make the information readily available to the public. This point was brought home by the Mexican crisis of December 1994.

\section{Appendix}

\section{Lemma 1: Indirect utility is an increasing function of future competency.}

Utility is evaluated at the optimal consumption profile. The first period incumbent is either $\mathrm{i}=\mathrm{nc}$ or $\mathrm{i}=\mathrm{c}$. Let $\rho$ be the likelihood that the second period incumbent is competent:

$$
\begin{aligned}
& \operatorname{Max} E U\left(c_{1} / i\right)=u\left(c_{1}\right)+\delta\left[\rho u\left(c_{2}^{i, c}\left(c_{1}\right)\right)+(1-\rho) u\left(c_{2}^{i, n c}\left(c_{1}\right)\right)\right] \\
& C_{1}
\end{aligned}
$$

For a given $\rho$, the first order condition for $c_{1}{ }^{i}$ that maximizes consumers' expected utility can be derived. To see how $\mathrm{c}_{1}{ }^{\mathrm{i}}$ reacts to changes in $\rho$, the first order condition must be differentiated totally. This yields the result that $c_{1}{ }^{i}$ is an increasing, continuous function of $\rho$ :

$$
\frac{d c_{1}^{i}}{d \rho}=\frac{\delta(1+i)\left[u^{\prime}\left(c_{2}^{i, c}\left(c_{1}{ }^{i}\right)\right)-u^{\prime}\left(c_{2}^{i, n c}\left(c_{1}{ }^{i}\right)\right)\right]}{\left.u^{\prime \prime}\left(c_{1}^{i}\right)+\delta(1+i)^{2}\left[\rho u^{\prime \prime}\left(c_{2}^{i, c}\left(c_{1}{ }^{i}\right)\right)+(1-\rho)\right) u^{\prime \prime}\left(c_{2}^{i, n c}\left(c_{1}{ }^{i}\right)\right)\right]}>0
$$

which affected episodes as the Primavera Plan. For two treatments of rational balance of payments crises, see Guidotti and Végh (1992) and Velasco (1994). 
The optimum level $c_{1}^{i}(\rho)$ can be plugged into the utility function of consumers, that now depends on $\rho$. Differentiating this value function and applying the envelope theorem, maximum expected utility is increasing in the likelihood that the second period incumbent is competent.

\section{Lemma 2: First period inflation is lower with a competent government .}

Consider an incompetent government. Given that it will not be reelected (under perfect information), the government sets the level of inflation $\pi_{1}{ }^{\mathrm{nc}}$ necessary to implement the optimal first-period consumption $\mathrm{c}_{1}{ }^{\text {nc }}$. Households then set aside resources $\mathrm{M}_{1}^{\mathrm{d}, \mathrm{nc}} / \mathrm{p}_{1}$ for future consumption. If the government is replaced by another incompetent, second period consumption will be lower and inflation higher than with a competent. In either case, the following equality must hold:

$$
C_{2}^{n c, c}\left(1+\underline{\Pi}_{2}\right)=C_{2}^{n c, n c}\left(1+\bar{\Pi}_{2}\right)=M_{1}^{d, n c} / p_{1}
$$

The first order condition for consumers, given expected inflation, is

$$
u^{\prime}\left(c_{1}^{n c}\right)=\delta\left[q u^{\prime}\left(c_{2}^{n c, c}\right) \frac{1}{1+\underline{\Pi}_{2}}+(1-q) u^{\prime}\left(c_{2}^{n c, n c}\right) \frac{1}{1+\bar{\Pi}_{2}}\right]
$$

Comparing this to the first order condition (11) for $\mathrm{i}=\mathrm{nc}$, we can infer that a weighted average of the expressions $1 /\left(1+\pi_{2}\right)$, where $\pi_{2}$ is either low or high, equals $(1+\mathrm{i})$. Since both weights are positive and add up to 1 , it follows that

$$
\underline{\Pi}_{2}<-\frac{i}{1+i}<\bar{\Pi}_{2}
$$

Using the budget restrictions for consumers and for the economy as a whole, we can derive the first period inflation when $\mathrm{i}=\mathrm{nc}$.

$$
\Pi_{1}^{n c}=\frac{M_{0} / p_{0}}{A^{n c, c}+C_{2}^{n c, c}\left[\frac{i}{1+i}+\underline{m}_{2}\right]}-1
$$


When $\mathrm{i}=\mathrm{c},(6)$ and (21) determine $\pi_{2}{ }^{\mathrm{c}}$, and $\pi_{1}{ }^{\mathrm{c}}$ follows from (1) and (2): ${ }^{13}$

$$
\Pi_{2}^{c}=-\frac{i}{1+i}, \quad \Pi_{1}^{c}=\frac{M_{0} / p_{0}}{A^{c, c}}-1
$$

Comparing (24) and (25), since $\mathrm{A}^{\mathrm{c}, \mathrm{c}}>\mathrm{A}^{\mathrm{nc}, \mathrm{c}}$ and $\mathrm{i} /(1+\mathrm{i})+\underline{\pi}_{2}<0$, we have $\pi_{1}^{\mathrm{nc}}>\pi_{1}{ }^{\mathrm{c}}$.

\section{Lemma 3: The cost of signaling is lower for a competent government.}

If the incumbent does not send signal $\mathrm{c}_{1}{ }^{\mathrm{s}}$, it will not be reelected. The best alternative for an incompetent is simply $\mathrm{c}_{1}{ }^{\mathrm{nc}}$, optimal given no reelection. For the competent, we can denote the best alternative to signaling as $\mathrm{c}_{1}{ }^{\text {nsc }}$ (where nsc stands for non-signaling competent), which does not distort the optimal consumption profile when the incumbent will not be reelected. The cost of signaling for each type is the difference between expected utility of consumers at $c_{1}^{s}$, where it is reelected, and either at $c_{1}^{\text {nc }}$ or $c_{1}^{\text {nsc }}$, where it is not reelected:

$$
\begin{aligned}
& c\left(c_{1}^{s}, c_{1}^{n c} / n c\right)=\delta q\left[u\left(c_{2}^{n c, c}\left(c_{1}^{n c}\right)\right)-u\left(c_{2}^{n c, n c}\left(c_{1}^{n c}\right)\right)\right] \\
& \quad+u\left(c_{1}^{n c}\right)+\delta u\left(c_{2}^{n c, n c}\left(c_{1}^{n c}\right)\right)-\left[u\left(c_{1}^{s}\right)+\delta u\left(c_{2}^{n c, n c}\left(c_{1}^{s}\right)\right]\right. \\
& C\left(c_{1}^{s}, c_{1}^{n s c} / c\right)=\delta(1-q)\left[u\left(c_{2}^{c, n c}\left(c_{1}^{n s c}\right)-u\left(c_{2}^{c, c}\left(c_{1}^{n s c}\right)\right)\right]\right. \\
& +u\left(c_{1}^{n s c}\right)+\delta u\left(c_{2}^{c, c}\left(c_{1}^{n s c}\right)\right)-\left[u\left(c_{1}^{s}\right)+\delta u\left(c_{2}^{c, c}\left(c_{1}^{s}\right)\right)\right]
\end{aligned}
$$

The signaling cost functions are both convex in $\mathrm{c}_{1}{ }^{\mathrm{s}}$. A fixed cost is associated with the change in probability of an incompetent being in office in the second period, and a variable cost depends on the upward

${ }^{13}$ In the case of a competent incumbent, there will be deflation in the second period, conforming to Friedman's rule on the optimum quantity of money. The government acts in this instance as a social planner that maximizes the welfare of society through its financial policy.

With the optimal policy, households will be indifferent between holding domestic money or switching to foreign bonds, if this were included in the model: in the second period they will either have a nominal amount of $M_{1}{ }^{d}$ or of $\left(M_{1}{ }^{d} / e_{1}\right)(1+i) e_{2}$, which equals $M_{1}{ }^{d}$ under (25). The intuition for this is that, under the optimal policy, the deflation (or appreciation of the exchange rate) exactly compensates the interest rate. For rates of devaluation and inflation $\pi_{2}$ above this optimal level, however, there is a temptation to hold foreign bonds. This possibility is ruled out in our model by the assumption that money is the only asset available to households. 
distortion of first period consumption. The minimum cost signal for each type does not distort the optimal pattern of consumption, so only the fixed cost is present at that level of consumption: for the incompetent, at the cost minimizing signal, the fixed component is positive, since the probability of an incompetent being in office in the second period increases from 1-q to 1 ; for the competent, at the cost-minimizing signal which coincides with the perfect information optimum $c_{1}{ }^{c}$, the cost is negative, since the probability of a second period competent government increases from $\mathrm{q}$ to 1 .

If the signal is $\mathrm{c}_{1}{ }^{\mathrm{s}}=\mathrm{c}_{1}^{\mathrm{c}}$, then $\mathrm{C}\left(\mathrm{c}_{1}^{\mathrm{s}}, \mathrm{c}{ }_{1}^{\mathrm{nsc}} / \mathrm{c}\right)<\mathrm{C}\left(\mathrm{c}^{\mathrm{s}}{ }_{\mathrm{s}}^{\mathrm{s}}{ }^{\mathrm{nc}} / \mathrm{nc}\right)$ must hold: the cost for the competent is negative, while the cost for the incompetent is positive even at its minimal level. Differentiating these two functions, it is possible to determine that the derivative of the incompetent's cost function is larger for all $\mathrm{c}_{1} \geq \mathrm{c}_{1}^{\mathrm{c}}$, so it remains above the competent's cost function for all the relevant range.

\section{Lemma 4: The cost of deviating from a pooling equilibrium is lower for a competent government .}

The argument is similar to Lemma 3. The cost of deviating for each type is the difference between expected consumer's utility at $c_{1}{ }^{d}$, where it is reelected for sure, and at $c_{1}$, phere it is reelected with probability $1 / 2$ :

$$
\begin{aligned}
& C\left(c_{1}^{d}, c_{1}^{p} / n C\right)=\delta \frac{q}{2}\left[u\left(c_{2}^{n c, c}\left(c_{1}^{p}\right)\right)-u\left(c_{2}^{n c, n c}\left(c_{1}^{p}\right)\right)\right] \\
& +u\left(c_{1}^{p}\right)+\delta u\left(c_{2}^{n c, n c}\left(c_{1}^{p}\right)\right)-\left[u\left(c_{1}^{d}\right)+\delta u\left(c_{2}^{n c, n c}\left(c_{1}^{d}\right)\right]\right. \\
& C\left(c_{1}^{d}, c_{1}^{p} / c\right)=\delta \frac{1-q}{2}\left[u\left(c_{2}^{c, n c}\left(c_{1}^{p}\right)-u\left(c_{2}^{c, c}\left(c_{1}^{p}\right)\right)\right]\right. \\
& +u\left(c_{1}^{p}\right)+\delta u\left(c_{2}^{c, c}\left(c_{1}^{p}\right)\right)-\left[u\left(c_{1}^{d}\right)+\delta u\left(c_{2}^{c, c}\left(c_{1}^{d}\right)\right)\right]
\end{aligned}
$$

The deviation cost functions are both convex in $\mathrm{c}_{1}^{\mathrm{d}}$, as can be verified by differentiation. Evaluated at $c_{1}=c_{1}{ }^{p}$, the deviation cost function is positive for the incompetent and negative for the competent. Differentiating them, the derivative of the incompetent's function is larger for all $c_{1} \geq c_{1}^{p}$, remaining above the competent's function. 


\section{References}

Bruno, Michael and Leora Meridor, 1991, The costly transition from stabilization to sustainable growth: Israel's case, in: M. Bruno et al., eds., Lessons of economic stabilization and its aftermath (MIT Press, Cambridge).

Calvo, Guillermo and Carlos Végh, 1990, Credibility and the dynamics of stabilization policy: a basic framework, IMF Working Paper WP/90/110.

Cardoso, Eliana, 1991, From inertia to megainflation: Brazil in the 1980s, in: M. Bruno et al., eds., Lessons of economic stabilization and its aftermath (MIT Press, Cambridge).

Cukierman, Alex and Allan Meltzer, 1986, A positive theory of discretionary policy, the cost of a democratic government, and the benefits of a constitution, Economic Inquiry 24, 367-388.

Cho, I.K and D. Kreps, 1987, Signaling games and stable equilibria, Quarterly Journal of Economics 102, 179-222.

De Gregorio, José, Pablo Guidotti and Carlos Végh, 1992, Inflation stabilization and the consumption of durables, mimeo, IMF.

Guidotti, Pablo and Carlos Végh, 1992, Losing credibility: The stabilization blues, IMF Working Paper WP/ 92/73.

Heymann, Daniel, 1991, From sharp disinflation to hyperinflation, twice: The Argentine experience, 1985-1989, in: M. Bruno et al., eds., Lessons of economic stabilization and its aftermath (MIT Press, Cambridge).

Kiguel, M. and N. Liviatan , 1992, The business cycle associated with exchange rate-based stabilizations, World Bank Economic Review 6, 279-305.

Krugman, Paul, 1979, A model of balance of payment crises, Journal of Money, Credit and Banking 11, 311-325.

Lucas, Robert, 1973, Some international evidence on output-inflation tradeoffs, American Economic Review 63, 326-334.

Mondino, Guillermo, Federico Sturzenegger and Mariano Tommasi, 1994, Recurrent high inflation and stabilization: A dynamic game, mimeo, UCLA.

Morales, Juan Antonio, 1991, The transition from stabilization to sustained growth in Bolivia, in: M. Bruno et al., eds., Lessons of economic stabilization and its aftermath (MIT Press, Cambridge). 
Nordhaus, William, 1975, The political business cycle, Review of Economic Studies 42, 169-190.

Persson, Torsten and Guido Tabellini, 1990, Macroeconomic policy, credibility and politics, (Harwood Academic Publishers, Chur).

Rogoff, Kenneth, 1990, Equilibrium political budget cycles, American Economic Review 80, 21-36.

Rogoff, Kenneth and Anne Sibert, 1988, Elections and macroeconomic policy cycles, Review of Economic Studies 55, 1-16.

Sargent, Thomas R. and Neil Wallace, 1981, Some unpleasant monetarist arithmetic, Federal Reserve Bank of Minneapolis Quarterly Review 5 (Fall), 1-17.

Velasco, Andrés, 1994, Are balance of payments crises rational?, C.V. Starr Center for Research Economics Working Paper No. 94-08, New York University.

Zarazaga, Carlos, 1994, Hyperinflations and moral hazard in the appropriation of seigniorage, mimeo, Federal Reserve Bank of Philadelphia. 


\section{Table I}

\section{Real Plan: Voting Intentions}

\section{Cardoso}

June

July

August

September

October (results)
$17 \%$

$27 \%$

$45 \%$

$43 \%$

$54 \%$
Lula

$39 \%$

$30 \%$

$23 \%$

$22 \%$

$27 \%$

Source: IBOPE, quoted in Clarín, September 14, 1994. 


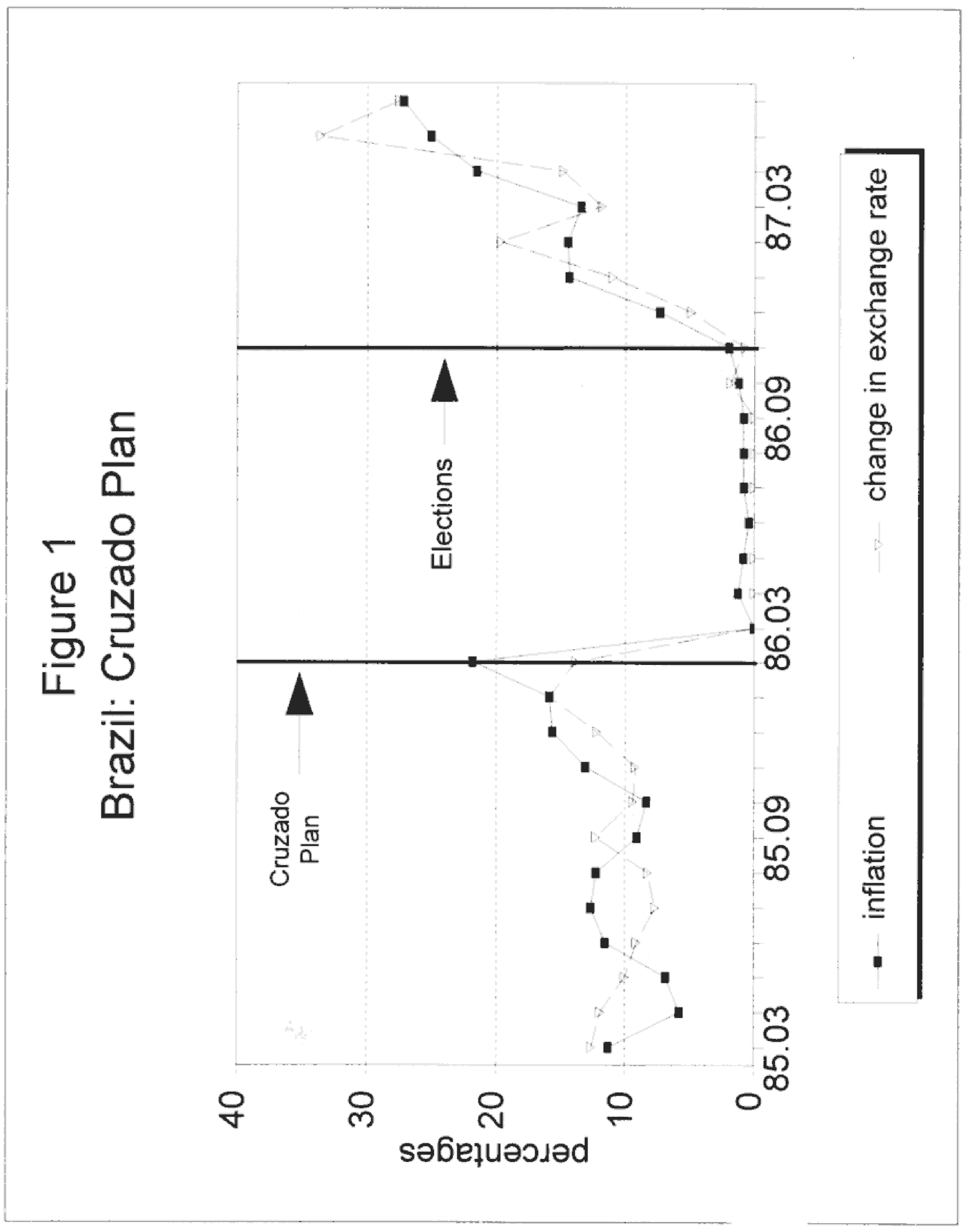




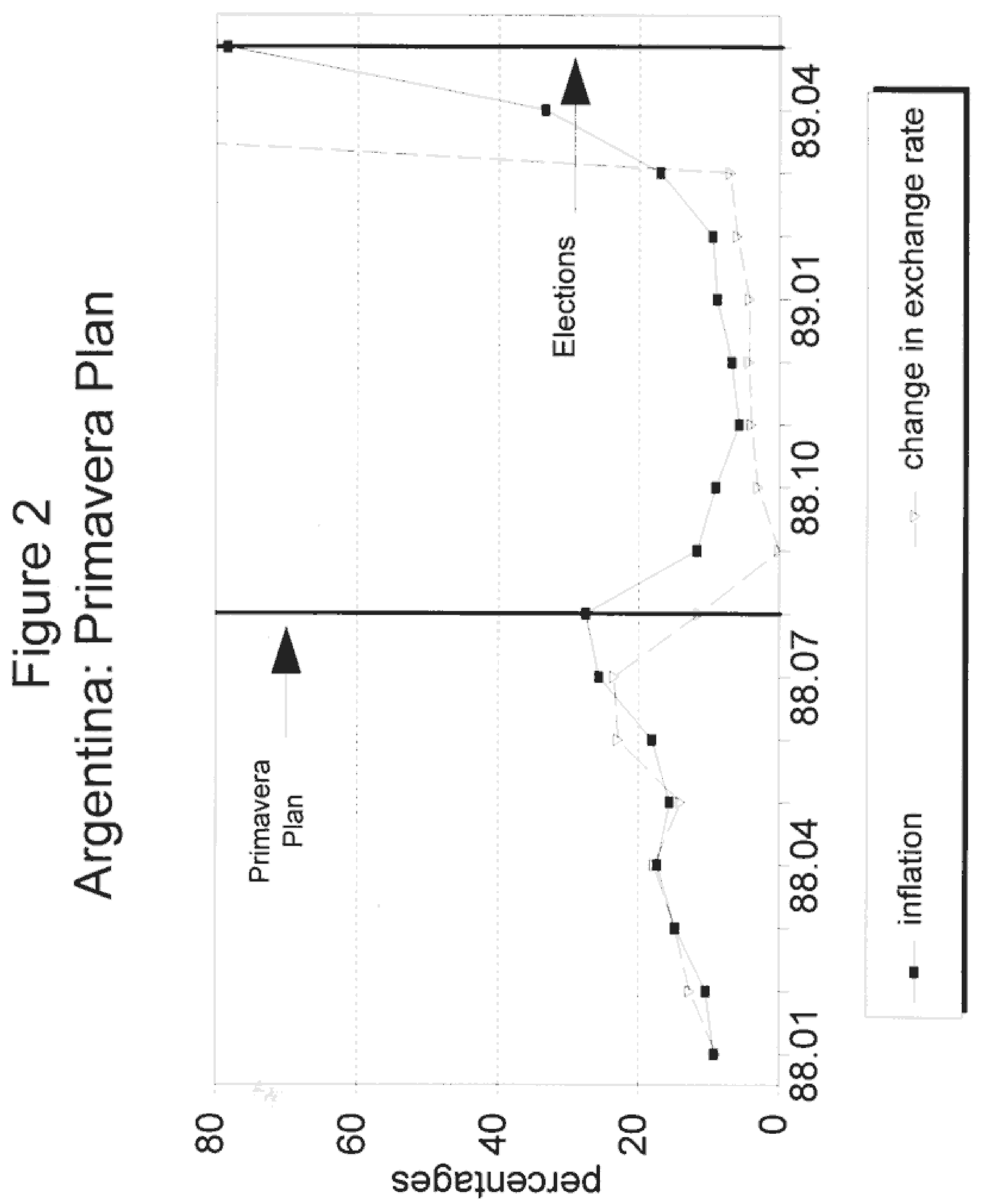




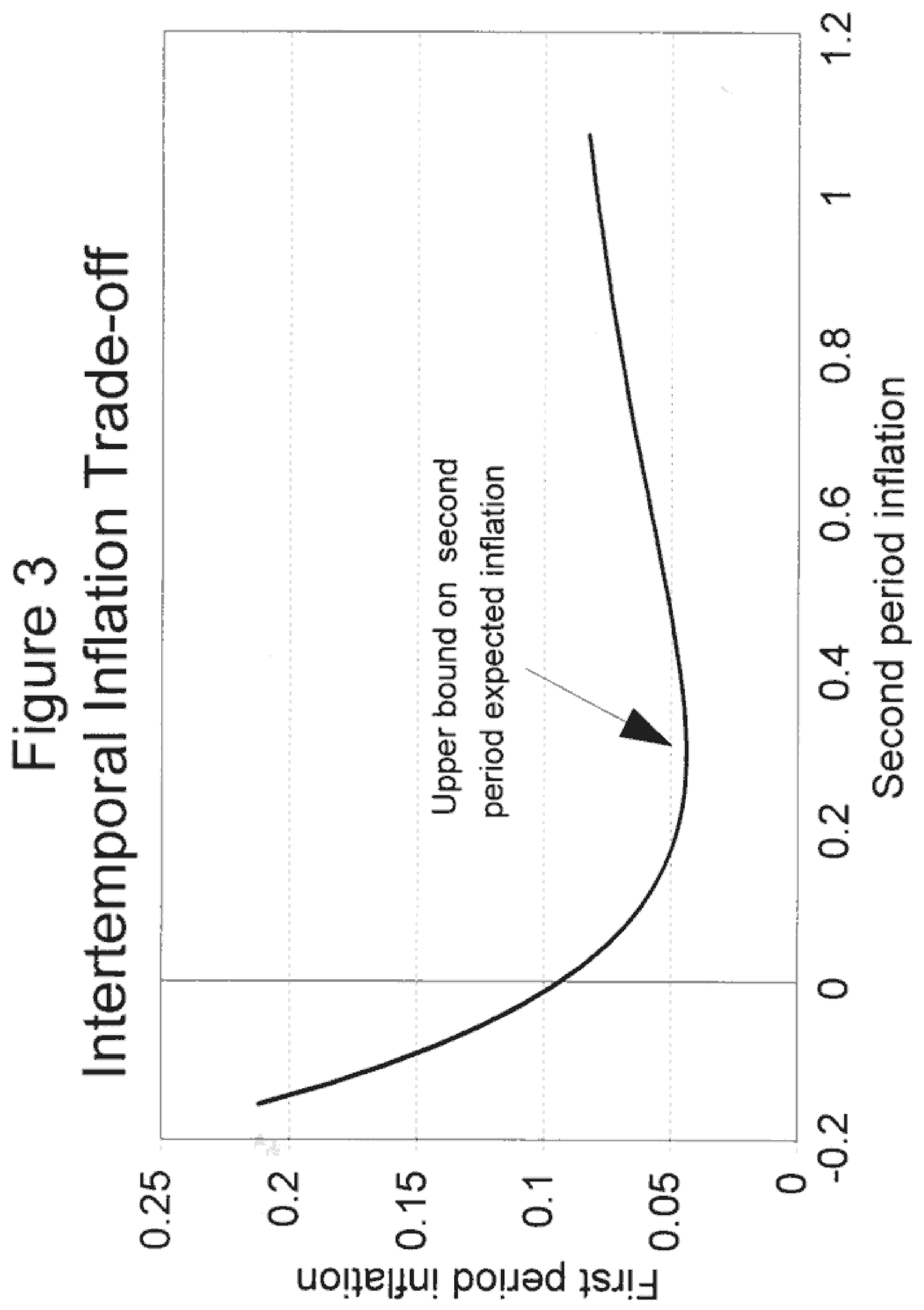




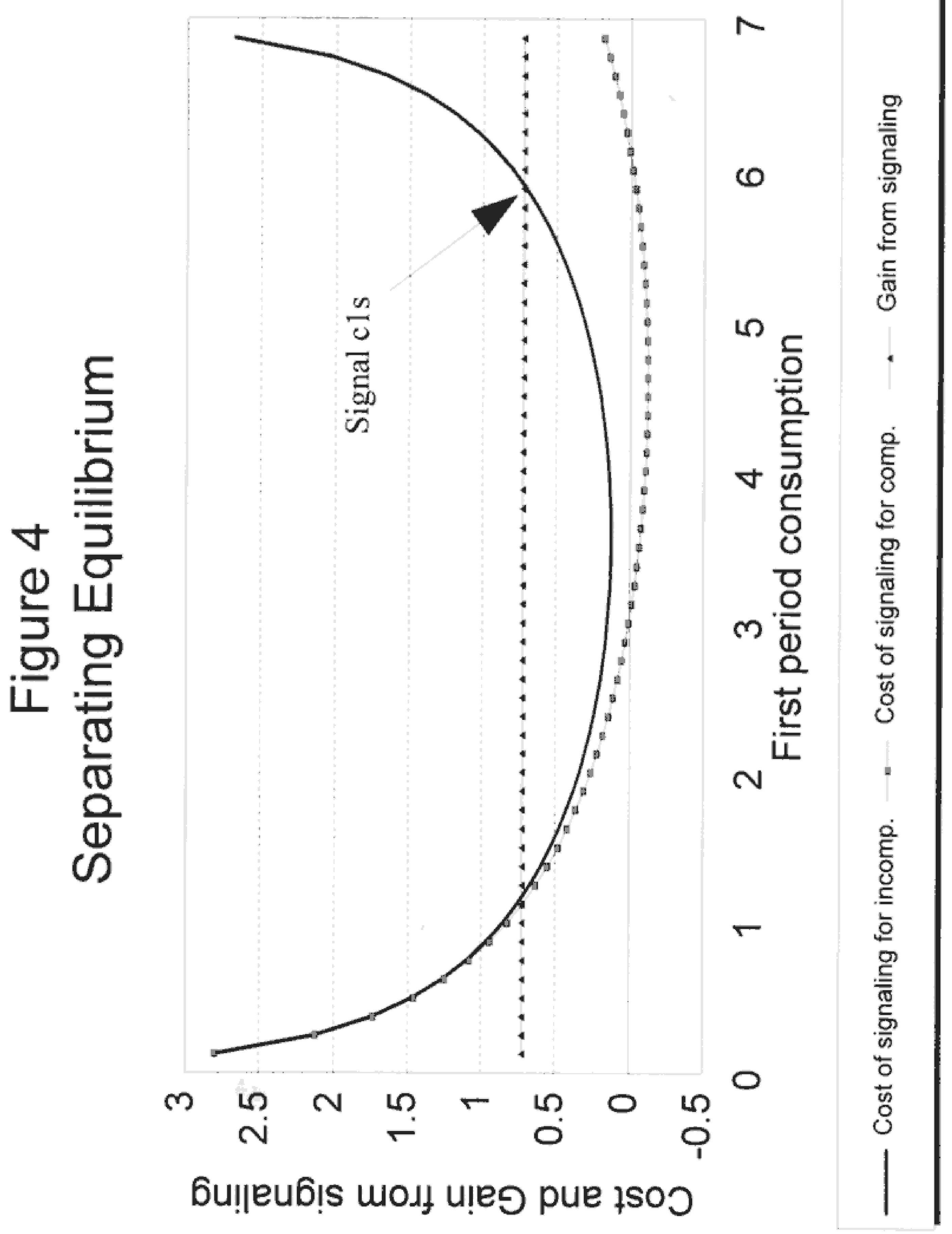




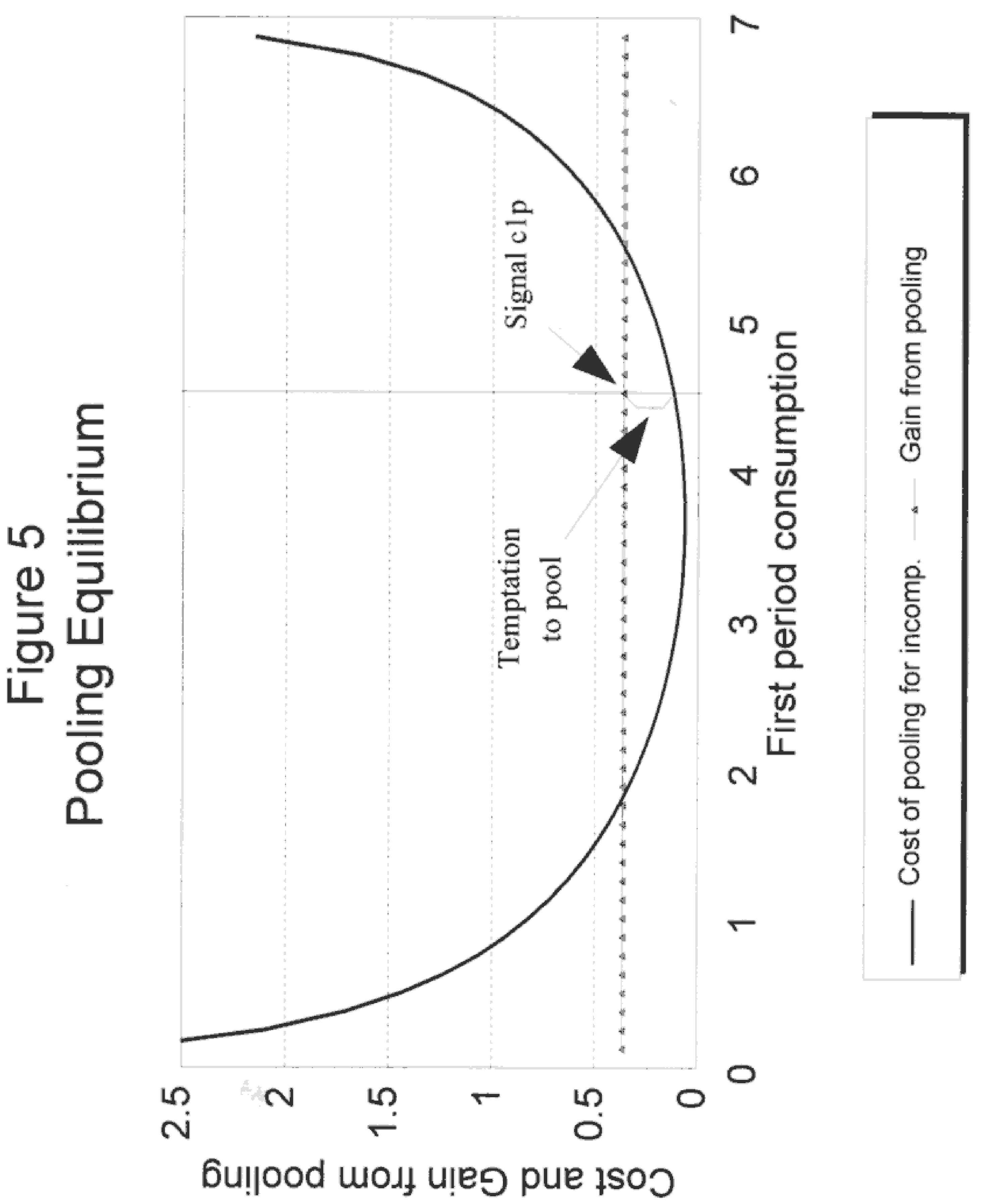




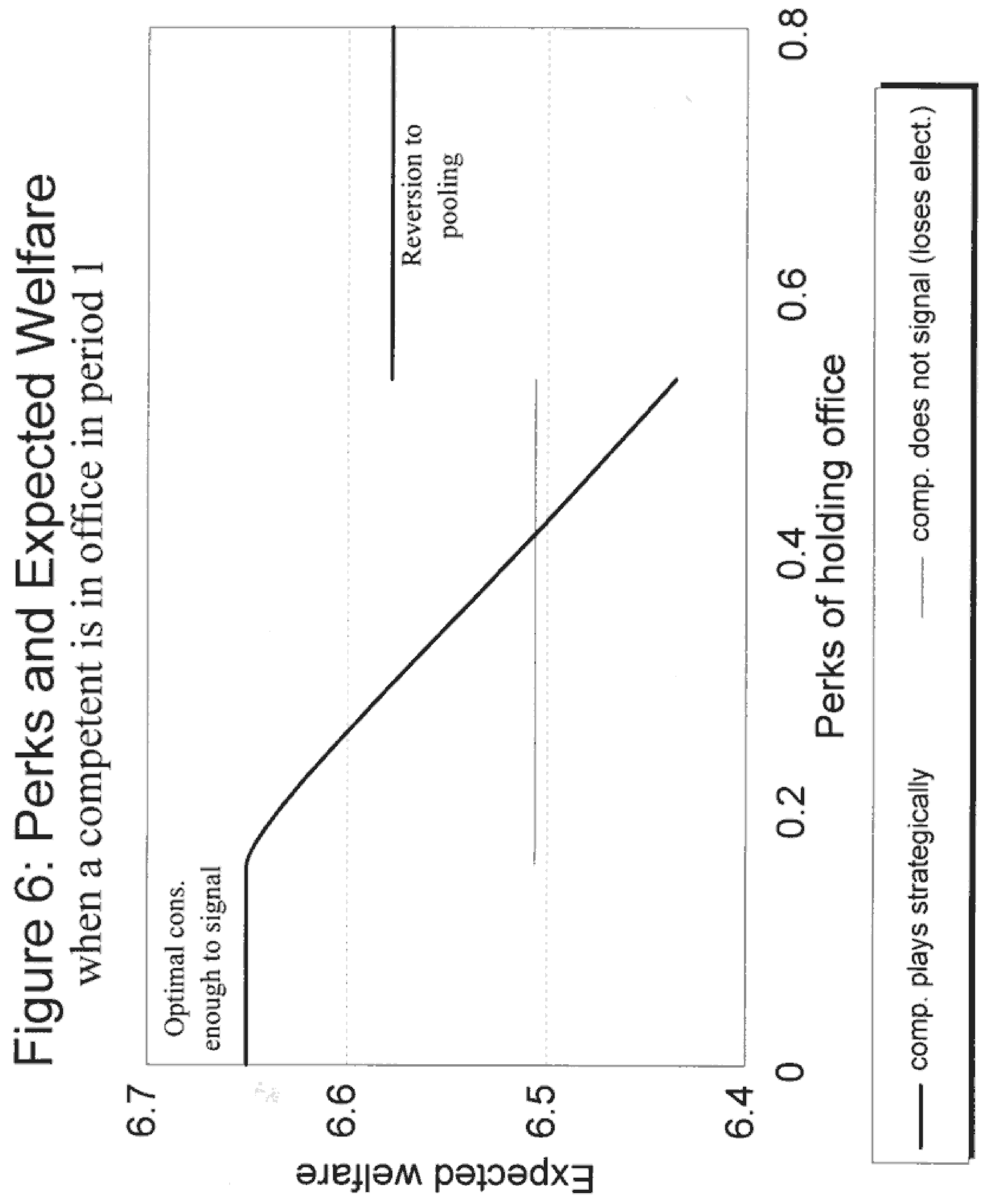

